\title{
Improvement of Sub-Base of Roads by Chemical Admixtures and Organic Materials
}

\author{
M. A. Mahmoud, M. S. Rabah, A. A. Mahmoud, N. M. Amin, A. M. Radwan
}

\begin{abstract}
One of the aspects of increase of earlier damage and failure of traffic load, especially in clayey regions, is the deficiency of pavement subgrade. To prevent such damage, strengthening of the pavement by improving the subgrade layer is essential. Many investigators have carried out research on the subgrade layer, especially when containing clay particles, using several types of additives (stabilizers).

Soil Stabilization is a method of improving the engineering properties of soil and therefore making it more stable. Generally, stabilization includes pre-consolidation, compaction and numerous other similar methods. However, stabilization is usually related to the processes which modify the soil composition itself for enhancement of its properties.

Soil stabilization of pavements is usually designed based on the assumption that specified levels of quality will be achieved for each soil layer in the pavement system. Each layer must resist shearing within the layer, avoid excessive elastic deformations that would result in fatigue cracking within the layer or in overlying layers, and prevent excessive permanent deformation through densification. Engineers are responsible for selecting or specifying the correct stabilizing method, technique, and quantity of material required.
\end{abstract}

Usually, the technology provides an alternative provision structural solution to a practical problem. The simplest stabilization processes are compaction and drainage. The other process is by improving gradation of particle size and further improvement can be achieved by adding binders to the weak soils.

This study showed that lime activated by sodium chloride in combination with sugar cane ash could be effectively used to improve soft clay with low soaked CBR value and high plasticity. Therefore, from the environmental point of view, it was recommended that sugar cane ash can partially replace lime in clay stabilization to form material with cementitous properties.

Key words: Clayey soil, Lime, Sodium chloride, Sugar cane ash, Strength, Swelling.

\section{INTRODUCTION}

The improvement of soil can be classified into several categories, modification or stabilization or both. The modification can be conducted by compaction or replacement

Revised Manuscript Received on February 05, 2020.

* Correspondence Author

Mahmoud Ali Mahmoud, Lecturer, Civil Engineering Dept, Helwan University, Cairo, Egypt. Email:DMahmoud_75@yahoo.com

Mohamed Rabah, Lecturer, Civil Engineering Dept, Russian University, Cairo, Egypt. Email: m.rabah@eru.edu.com

Ahmed Abd Elghani Mahmoud, Lecturer, Civil Engineering Dept, Helwan University, Cairo, Egypt. Email: traffic_roads@yahoo.com

Nourhan mahmoud Amin, Ass. Lecturer, Civil Engineering Dept, Russian University, Cairo, Egypt. Email: norhanmahmoud350@gmail.com

Amr Mohamed Radwan, Prof, Civil Engineering Dept, Helwan University, Cairo, Egypt. Email: aamrrad183@yahoo.com

(C) The Authors. Published by Blue Eyes Intelligence Engineering and Sciences Publication (BEIESP). This is an open access article under the CC BY-NC-ND license (http://creativecommons.org/licenses/by-nc-nd/4.0/) of the original soil or mixing soil with another. While stabilization is the treatment of soils to enable their strength and durability to be improved such that they become totally suitable for construction.

Stabilization of pavement subgrade soils has traditionally relied on treatment with lime, cement, or waste materials such as sugar cane ash, fly ash, slags, silica fume, etc. Many researchers have been looking for waste and economical materials to be used in soil stabilization. Cement and lime are the familiar materials used for stabilizing soils. These materials have rapidly increased in price, especially cement, due to the sharp increase in energy cost. Since sugar cane ash (SCA) is considered one of the cheaper materials in Egypt, therefore, sugar cane is one of the most significant economic products for many countries like Brazil, India, Pakistan and few of Arab countries like Egypt, Sudan and Iraq. Production of sugar cane in Brazil is the highest of the world, followed by India, China, Thailand, Mexico, Pakistan, Australia and Cuba. For Arab countries, sugar cane is grown in a few of them, and Egypt is one of the most Arab countries production of sugar cane, followed by Sudan, while grown in limited areas in Iraq, Morocco and Lebanon (Masued, 2017).

After the development has reapeared in the industry of sugar in Maysan factory, it means that the environment will get more agricultural waste material. With the new approach of science which includes recycling these waste materials, and re-use it to be friendly to environment in different approaches, especially in highway construction, this has encouraged researchers to investigate this approach for using these materials (Masued, 2017).

Mahapatra and Sahoo (2017) pointed out that in sugar industry sugar cane straw is produced as major by-product during manufacturing of sugar. Bagasse ash agricultural by-product of sugar cane is used by incineration to generate electricity. Its improper deposit poses a serious environmental problem. The strength and stiffness of soft soil is believed to be improved by adding these wastes with fibers together with chemical agent. Sugar cane bagasse ash is believed to contain silicon oxide at high percentage with pozzolanic behavior. As pozzolanic material sugar cane bagasse ash is also believed to contain oxides of aluminum, silica and calcium. Stabilization of natural soil with sugar cane bagasse ash is believed to be an effective means of chemical stabilization (Mir et al, 2013). Barasa et al (2013) stated that general decrease in liquid limit for the combination of lime and bagasse ash with soil particles was attributed to the fact that the compounds formed possess cementitous properties due to calcium silicate. This trend conformed the findings of Muntohar and Hantoro (2000) who found that the liquid limit reduced with increasing lime and rice husk ash combinations. 
The effect was also due to the partial replacement of high plastic particles of clay with the low plasticity lime and sugar cane bagasse ash (SCBA) particles. The ratio of lime to ash gave positive results of reduction in plasticity index, linear shrinkage and swelling, although the effect of ash on the plasticity and linear shrinkage of cohesive soils are remarkable, but are inferior to those which occur by addition of lime only. They also added that CBR values increased with the increase in the quantity of lime added, but decreased when sugar cane bagasse ash alone was added. When the blended mixture of lime and ash was used the CBR increased remarkably because of the reaction between calcium and silicate. The ash being alkaline when mixed with the sample in the presence of lime and moisture, the $\mathrm{PH}$ is lowered; hence more as silica from clay dissolved and facilitated pozzolanic reaction.

\section{MATERIALS AND METHODOLOGY}

The soil used in this study was obtained beside the bridge crossing Cairo-Alexandria Road. Hydrated lime $\mathrm{Ca}(\mathrm{OH}) 2$ was obtained from 10th of Ramadan City-Sharkia-Egypt. Sugar cane ash was purchased from a local hardware store. Firstly, it was washed by water to remove undesirable materials such as sand grains, then it was dried in air for 3 to 4 days, then dried in the oven. The obtained material was pulverized and passed firstly through sieve No. 40, for check by removing large size particles, and finally through sieve No. 200 to obtain final ash stabilizer. Specific gravity of sugar cane ash is found to be at least 1.93. This may be due to its fibrous nature and very light weight. Figure (1) shows a sample of sugar cane ash used in this study.

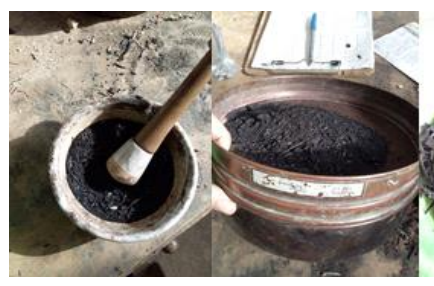

(a) Before preparation

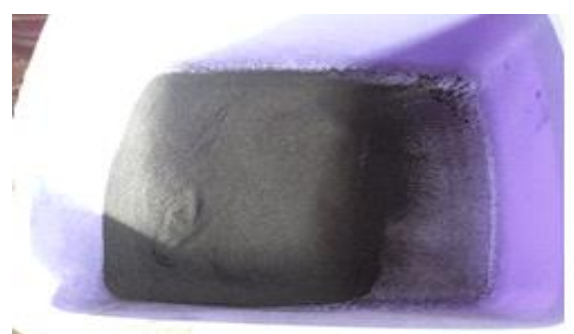

(b) After preparation for use as stabilizer

Fig. 1.Sugar cane ash stabilizer.

Table- 1: Physical properties of the used soil

\begin{tabular}{|c|c|}
\hline Physical Properties & Result \\
\hline \hline Liquid Limit (L.L) & 64.45 \\
\hline Plastic Limit (P.L) & 37.96 \\
\hline Maximum Dry Density (MDD) gm/cm3 & 26.49 \\
Optimum Moisture Content (OMC) \% & 1.91 \\
\hline
\end{tabular}

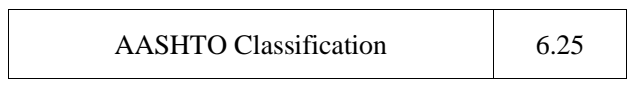

Particle size distribution tests were carried out using the hydrometer for the two gradations of the test soil as shown in Figures (2) and (3).

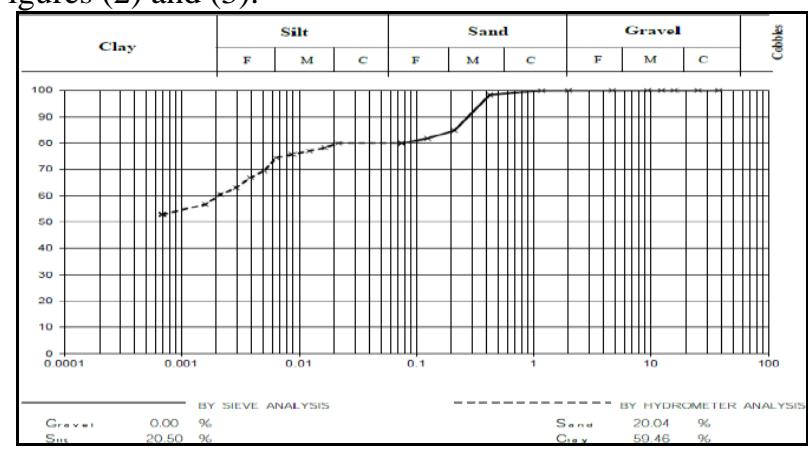

Fig. 2.Grain size distribution of soil (1).

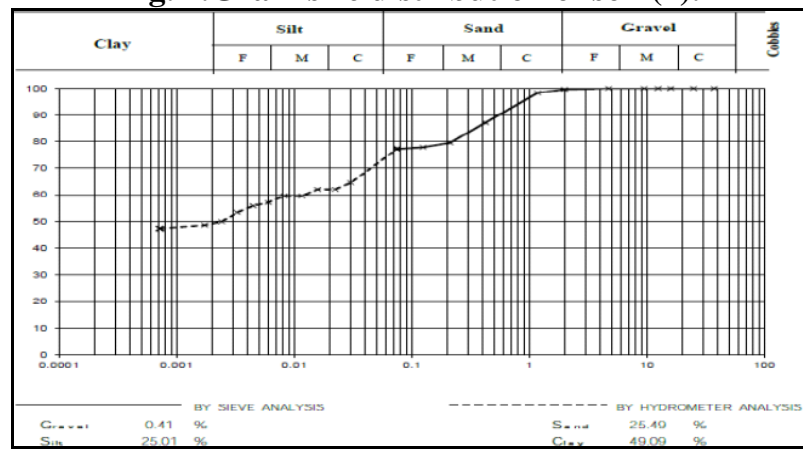

Fig. 3.Grain size distribution of soil (2).

The soil was classified into two gradations: i) soil (1) which passed sieve (40) and was used for finding swelling (S\%) and plasticity characteristics, ii) soil (2) which passed sieve (8) and was used in California bearing ratio ( CBR) and compaction tests. Table (1) shows the physical properties of the tested soil. Table (2) shows the chemical composition of soil, lime (L), and sugar cane ash (SCA).

Table- 2: Chemical properties of tested soil hydrated Lime and sugar cane ash.

\begin{tabular}{|c|c|c|c|}
\hline Component & L & Ash & Soil \\
\hline \hline $\mathrm{SiO} 2$ & 1.92 & 26.94 & 52.39 \\
\hline $\mathrm{Fe} 2 \mathrm{O} 3$ & 0.62 & 1.50 & 17.32 \\
\hline $\mathrm{CaO}$ & 50.71 & 8.54 & 3.84 \\
\hline $\mathrm{MgO}$ & 0.31 & 5.29 & 2.61 \\
\hline $\mathrm{Na} 2 \mathrm{O}$ & 1.71 & 3.11 & 0.47 \\
\hline $\mathrm{K} 2 \mathrm{O}$ & 0.24 & 21.40 & 1.45 \\
\hline $\mathrm{LOI}$ & - & 8.75 & - \\
\hline $\mathrm{Al} 2 \mathrm{O} 3$ & 0.15 & 1.66 & 12.40 \\
\hline $\mathrm{TiO} 2$ & 0.03 & 0.17 & 2.72 \\
\hline $\mathrm{SO} 3$ & 12.63 & 7.95 & 001 \\
\hline $\mathrm{P} 2 \mathrm{O} 5$ & $<0.01$ & 8.18 & 0.13 \\
\hline
\end{tabular}




\begin{tabular}{|c|c|c|c|}
\hline CL- & - & 6.41 & - \\
\hline $\mathrm{MnO}$ & 0.01 & 0.05 & 0.27 \\
\hline
\end{tabular}

\section{RESULTS AND DISCUSSIONS}

\section{PLASTICITY TESTS}

The Atterberg limit test was carried out in accordance with ASTMD 4318 - Standard Test Method for Liquid Limit (L.L), Plastic Limit (P.L), and Plasticity Index (P.I) of Soils.

Table (3) shows the results of Atterberg limits and Figures (3), (4) and (5) show the results of L.L, P.L and P.I, respectively, for samples treated with $\mathrm{L}$ only activated by $10 \% \mathrm{NaCl}$, sugar cane ash, and combination of L activated by $10 \% \mathrm{NaCl}$ and SCA by ratios (4:1), (3:2) and (2:3).

As mentioned by Muntohar and Hantoro (2000) and Abd.El- Aziz et al (2004), the L.L slightly decreased, while P.L increased, thus a reduction in P.I was obtained, whether adding $\mathrm{L}$ activated by $\mathrm{NaCl}$ or combination of $\mathrm{L}$ and SCA to the test soil. As mentioned by Masued (2017), Barasa et al, (2013) the L.L slightly increased, while P.L decreased, thus increase in P.I was obtained. No lime fixation point was observed in all combinations of additives.

Table- 3: Atterberg limits for using $L$ activated by $10 \%$ $\mathrm{NaCl}$, sugar cane ash, and combination of $\mathrm{L}$ activated by $10 \% \mathrm{NaCl}$ and SCA by ratios $(4: 1),(3: 2)$ and $(2: 3)$

\begin{tabular}{|c|c|c|c|c|c|}
\hline \multicolumn{6}{|c|}{ Liquid Limit (L.L) } \\
\hline \hline $\begin{array}{c}\text { Mix } \\
\text { No. }\end{array}$ & $\% L+N a C L$ & $\% S C A$ & $\begin{array}{c}\% \text { LCA Ratio } \\
(4: 1)\end{array}$ & $\begin{array}{c}\% L: S C A \\
b y \text { Ratio } \\
(3: 2)\end{array}$ & $\begin{array}{c}\% \text { L:SCA } \\
\text { by Ratio } \\
(2: 3)\end{array}$ \\
\hline 1 & 64.45 & 64.45 & 64.45 & 64.45 & 64.45 \\
\hline 2 & 54.61 & 81.7 & 43.59 & 58.26 & 61.27 \\
\hline 3 & 51.11 & 79.4 & 47.01 & 58.2 & 59.84 \\
\hline 4 & 50.99 & 82.43 & 51.88 & 59.29 & 56.89 \\
\hline & & Plastic Limit (P.L) & \\
\hline \hline 1 & 37.96 & 37.96 & 37.96 & 37.96 & 37.96 \\
\hline 2 & 38.44 & 47.85 & 38.14 & 48.89 & 44.31 \\
\hline 3 & 38.22 & 45.55 & 44.21 & 46.11 & 49.66 \\
\hline 4 & 40.54 & 44.86 & 47.91 & 53.1 & 48.42 \\
\hline & & \multicolumn{7}{|c|}{ Plasticity Index (P.I) } & \\
\hline \hline 1 & 26.47 & 26.47 & 26.47 & 26.47 & 26.47 \\
\hline 2 & 16.17 & 33.85 & 5.44 & 9.37 & 16.96 \\
\hline 3 & 12.89 & 33.85 & 2.8 & 12.09 & 10.18 \\
\hline 4 & 10.45 & 37.57 & 3.97 & 6.23 & 8.47 \\
\hline
\end{tabular}

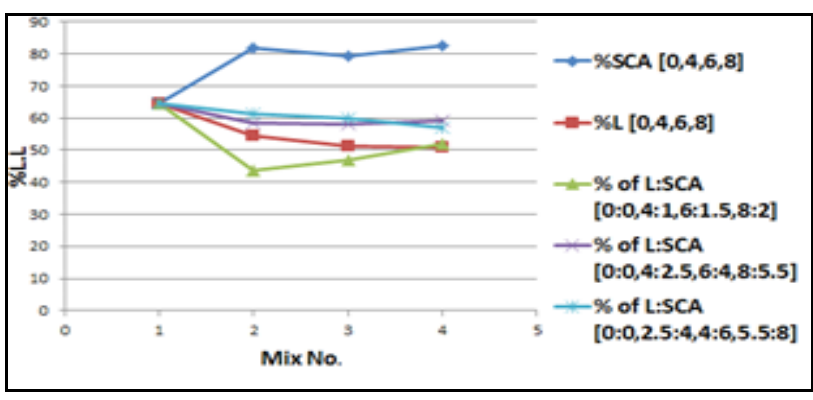

Fig. 4.Effect of adding $\mathrm{L}$ activated by $10 \% \mathrm{NaCl}$, sugar cane ash, and combination of $L$ activated by $10 \%$
$\mathrm{NaCl}$ and SCA by ratios (4:1), (3:2) and (2:3) on liquid limit.

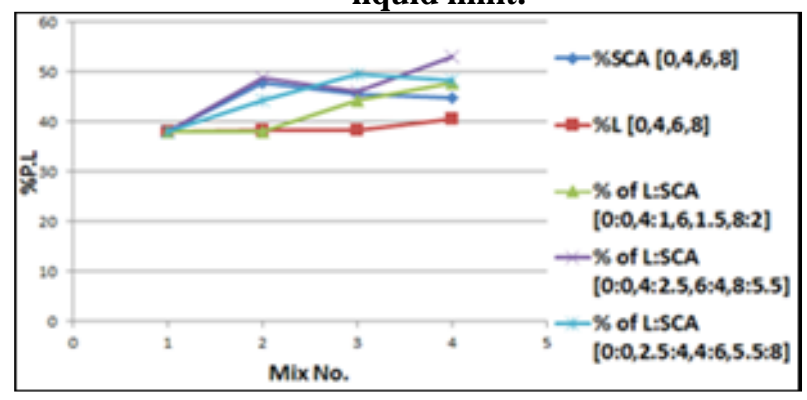

Fig. 5. Effect of adding $\mathrm{L}$ activated by10\% $\mathrm{NaCl}$, sugar cane ash, and combination of $\mathrm{L}$ activated by $10 \% \mathrm{NaCl}$ and SCA by ratios (4:1), (3:2) and (2:3) on platic limit.

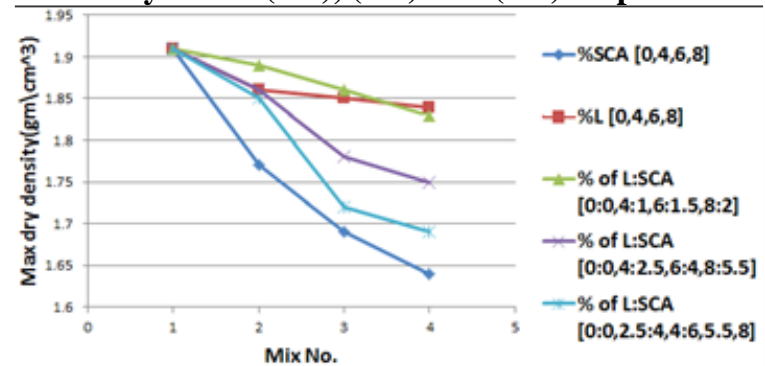

Fig. 6. Effect of adding $\mathrm{L}$ activated by10\% $\mathrm{NaCl}$, sugar cane ash, and combination of $\mathrm{L}$ activated by $10 \% \mathrm{NaCl}$ and SCA by ratios (4:1), (3:2) and (2:3) on plasticity limit.

\section{COMPACTION TESTS}

The modified proctor test was performed in laboratory in accordance to BS 1377: 1990. The relationship between L activated by $10 \% \mathrm{NaCl}$, sugar cane ash, and combination of $\mathrm{L}$ activated by $10 \% \mathrm{NaCl}$, SCA by ratio (4:1), (3:2) and (2:3), maximum dry density (MDD) and optimum moisture content (OMC) is shown in table (4). Figures (7) and (8) show the relationship between the maximum dry density (MDD), the optimum moisture content (OMC) and total additives respectively.

It is observed that generally MDD decreases with the increase in $\mathrm{L}$ percentage, whether the activator is $\mathrm{NaCl}$ or SCA. Also, the reduction percentage in MDD is greater in case of SCA as the percentages of SCA added are higher than the L. This may be due to the unit weight of soil is higher than $\mathrm{L}$ or SCA. Therefore, the reduction in MDD is greater at the same L percentages. As mentioned by Ouf (2001) and Abd.El- Aziz et al (2004), the addition of L and combination of (L+SCA) to the test soil decreased the MDD and increased the OMC. Same findings were given by Masued (2017).

Table- 4: Compaction characteristics for using $L$ activated by $10 \% \mathrm{NaCl}$, sugar cane ash, and combination of $L$ activated by $10 \% \mathrm{NaCl}$ and SCA by ratios (4:1),(3:2) and (2:3)

\begin{tabular}{|c|c|c|c|c|c|}
\hline \multicolumn{6}{|c|}{ Maximum dry density (MDD) } \\
\hline \hline $\begin{array}{c}\text { Mix } \\
\text { no. }\end{array}$ & $\% L+N a C L$ & $\% S C A$ & $\begin{array}{c}\% L: S C A \text { by } \\
\text { Ratio (4:1) }\end{array}$ & $\begin{array}{c}\% L: S C A \text { by } \\
\text { Ratio (3:2) }\end{array}$ & $\begin{array}{c}\% L: S C A \text { by } \\
\text { Ratio (2:3) }\end{array}$ \\
\hline 1 & 1.91 & 1.91 & 1.91 & 1.91 & 1.91 \\
\hline 2 & 1.86 & 1.77 & 1.89 & 1.86 & 1.85 \\
\hline 3 & 1.85 & 1.69 & 1.86 & 1.78 & 1.72 \\
\hline 4 & 1.84 & 1.64 & 1.83 & 1.75 & 1.69 \\
\hline
\end{tabular}




\begin{tabular}{|c|c|c|c|c|c|}
\hline \multicolumn{7}{|c|}{ Optimum moisture content (OMC) } \\
\hline \hline 1 & 6.25 & 6.25 & 6.25 & 6.25 & 6.25 \\
\hline 2 & 6.77 & 8.41 & 8.48 & 8.83 & 8.96 \\
\hline 3 & 6.93 & 8.52 & 8.65 & 8.91 & 8.83 \\
\hline 4 & 6.95 & 8.96 & 8.53 & 8.84 & 8.71 \\
\hline
\end{tabular}

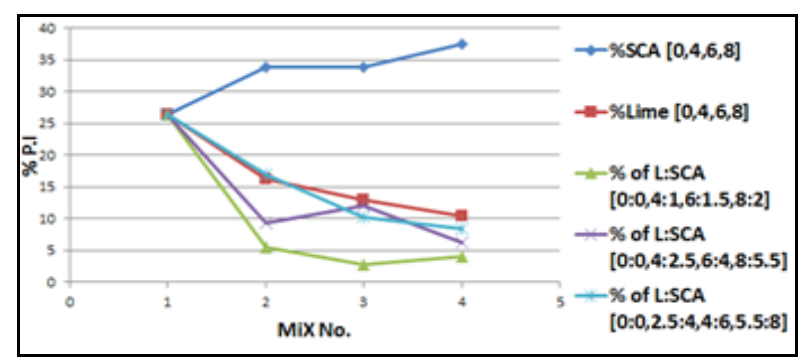

Fig. 7.Effect of adding $\mathrm{L}$ activated by $10 \% \mathrm{NaCl}$, sugar cane ash, and combination of $\mathrm{L}$ activated by $10 \% \mathrm{NaCl}$ and SCA by ratios (4:1), (3:2) and (2:3) on the maximum dry density.

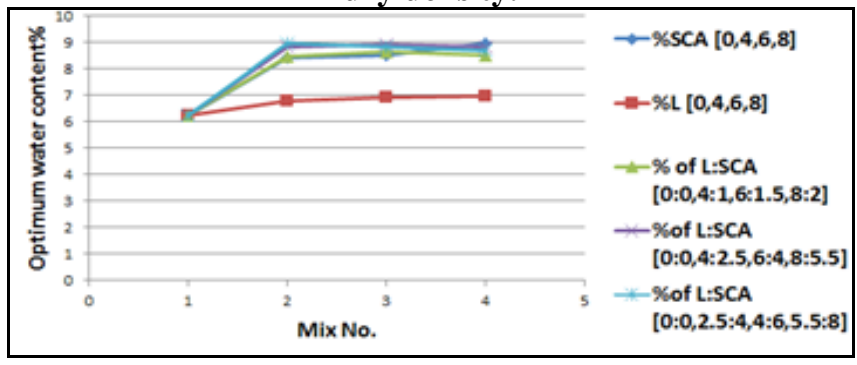

Fig. 8.Effect of adding $L$ activated by $10 \% \mathrm{NaCl}$, sugar cane ash, and combination of $\mathrm{L}$ activated by $10 \% \mathrm{NaCl}$ and SCA by ratios (4:1), (3:2) and (2:3) on the optimum moisture content.

\section{CALIFORNIA BEARING RATIO (CBR) TESTS}

The CBR test is always carried out at un-soaked and soaked conditions. The case of soaked condition was carried out in this study, this test is used in evaluation of the strength of the tested soil such as subgrade, subbase and base soils for flexible pavement design (AASHTO Designation T 193-99, 2003).

Figure (9) and table (5) show the effect of adding $\mathrm{L}$ activated by $10 \% \mathrm{NaCl}$, sugar cane ash, and combination of $\mathrm{L}$ activated by $10 \% \mathrm{NaCl}$ and SCA by ratios (4:1), (3:2) and (2:3) on CBR of the investigated soil. The results indicates that the CBR increases with an increase in $\mathrm{L}$ activated by $10 \% \mathrm{NaCl}$ to a maximum value from $22.14 \%$ to $54.23 \%$ at $8 \% \mathrm{~L}+10 \% \mathrm{NaCl}$, and increased with combination of $\mathrm{L}$ activated by $10 \% \mathrm{NaCl}$ and SCA to a maximum value from $22.14 \%$ to $78.64 \%$ at $6 \% \mathrm{~L}+1.5 \%$ SCA. The results indicated that the CBR increased with combination of $\mathrm{L}$ activated by $10 \% \mathrm{NaCl}$ and SCA even more than $\mathrm{L}$ activated by $10 \%$ $\mathrm{NaCl}$ alone. But, the CBR decreased when adding SCA alone to the test soil, Figure (10). The increase of the CBR is attributed to the formation of cementitous compounds between the calcium oxide $(\mathrm{CaO})$ present in lime and silica present in the soil and SCA. These test results agree with the findings of Bachchhas and Soni, (2017), Mahapatra and Sahoo (2017), Negi et al (2013), Mohamed et al (1991), Milburn and Parsons (2004) and Ahmed (1988).

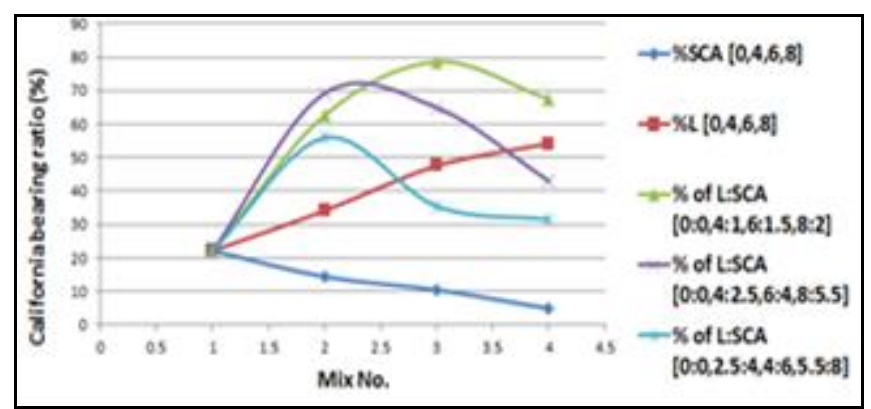

Fig. 9. Effect of adding $\mathrm{L}$ activated by10\% $\mathrm{NaCl}$, sugar cane ash, and combination of $\mathrm{L}$ activated by $10 \% \mathrm{NaCl}$ and SCA by ratios (4:1), (3:2) and (2:3) on the California bearing ratio (CBR)\%.

Fig. 10.

Table- 5: California bearing ratio (CBR) of using $L$ activated by $10 \% \mathrm{NaCl}$, sugar cane ash, and combination of $L$ activated by $10 \% \mathrm{NaCl}$ and SCA by ratios (4:1),(3:2) and (2:3)

\begin{tabular}{|c|c|c|c|c|c|}
\hline \multicolumn{5}{|c|}{ California bearing ratio (CBR)\% } \\
\hline $\begin{array}{c}\text { Mix } \\
\text { No. }\end{array}$ & $\% L+N a C L$ & $\% S C A$ & $\begin{array}{c}\% L: S C A \\
\text { by Ratio } \\
(4: 1)\end{array}$ & $\begin{array}{c}\% L: S C A \\
\text { by Ratio } \\
(3: 2)\end{array}$ & $\begin{array}{c}\% \text { L:SCA by } \\
\text { Ratio (2:3) }\end{array}$ \\
\hline 1 & 22.14 & 22.14 & 22.14 & 22.14 & 22.14 \\
\hline 2 & 34.10 & 14.36 & 62.65 & 69.24 & 55.90 \\
\hline 3 & 47.53 & 10.43 & 78.64 & 64.92 & 35.43 \\
\hline 4 & 54.23 & 4.86 & 67.41 & 43.00 & 31.43 \\
\hline
\end{tabular}

\section{SWELLING TESTS}

The results of S\% tests are shown in Table (6) and Figure (10) for curing periods of 4 days. It is found that the S\% percentage dramatically decreases by adding L only activated by $10 \% \mathrm{NaCl}$ to the soil. Ouf (2001), Milburn and Robert (2004) agreed with the obtained results. S\% also reduces when adding combination of $\mathrm{L}$ activated by $10 \%$ $\mathrm{NaCl}$ and SCA, but the S\% increases when adding SCA alone to the soil. The optimum percentages in reduction in $\% \mathrm{~S}$ are at combination of $8 \% \mathrm{~L}$ activated by $10 \% \mathrm{NaCl}$ in chemical additives, and $6 \% \mathrm{~L}$ activated by $10 \% \mathrm{NaCl}$, and $1.5 \%$ SCA for combination between chemical and organic additives.

Table- 6: Swelling percentage (\%S) of using $L$ activated by $10 \% \mathrm{NaCl}$, sugar cane ash, and combination of $\mathrm{L}$ activated by $10 \% \mathrm{NaCl}$ and SCA by ratios (4:1),(3:2) and (2:3)

\begin{tabular}{|c|c|c|c|c|c|}
\hline \multicolumn{7}{|c|}{ Swelling percentage (S\%) } \\
\hline \hline $\begin{array}{c}\text { Mix } \\
\text { No. }\end{array}$ & $\% L+N a C L$ & $\% S C A$ & $\begin{array}{c}\% \text { L:SCA } \\
\text { by Ratio } \\
(4: 1)\end{array}$ & $\begin{array}{c}\% \text { L:SCA } \\
\text { by Ratio } \\
(3: 2)\end{array}$ & $\begin{array}{c}\% \text { L:SCA by } \\
\text { Ratio }(2: 3)\end{array}$ \\
\hline 1 & 107.22 & 107.22 & 107.22 & 107.22 & 107.22 \\
\hline 2 & 55.47 & 126.17 & 34.86 & 8.78 & 36.35 \\
\hline 3 & 45.74 & 151.22 & 10.43 & 21.04 & 16.43 \\
\hline
\end{tabular}




\begin{tabular}{|l|l|l|l|l|l|}
\hline 4 & 35.04 & 163.04 & 33.21 & 31.13 & 21.04 \\
\hline
\end{tabular}

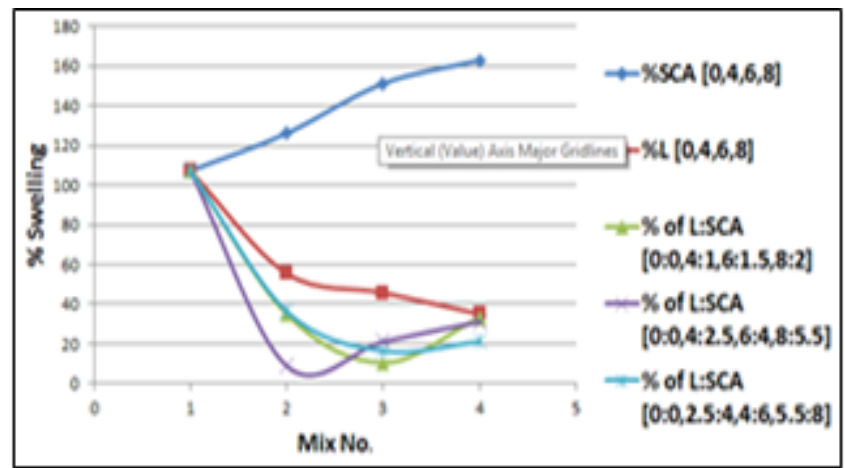

Fig. 11. Effect of adding $L$ activated by10\% $\mathrm{NaCl}$, sugar cane ash, and combination of $\mathrm{L}$ activated by $10 \% \mathrm{NaCl}$ and SCA by ratios (4:1), (3:2) and (2:3) on swelling percentage $(\% \mathrm{~S})$.

IV. OPTIMUM RATIO OF SUGARCANE ASH AS PARTIAL REPLACEMENT OF LIME ACTIVATED BY 10\% NACL IN STABILIZATION OF SOFT CLAY SOILS

\section{EFFECT ON PLASTICITY CHARACTERISTICS}

The optimum percentages of $\mathrm{L}$ activated by $10 \% \mathrm{NaCl}$, sugar cane ash and combination of L activated by $10 \% \mathrm{NaCl}$ and SCA by ratios (4:1),(3:2) and (2:3) effect on plasticity index are shown in figure (11).

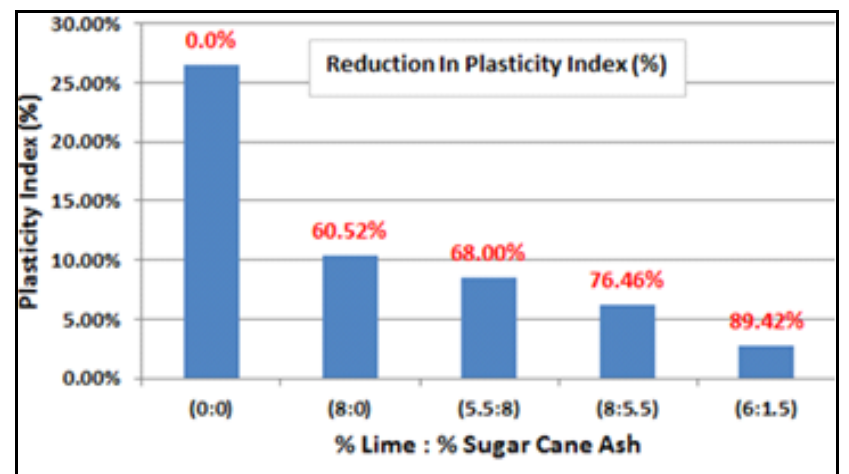

Fig. 12. The optimum percentages of $L$ activated by $10 \% \mathrm{NaCl}$, sugar cane ash, and combination of $\mathrm{L}$ activated by $10 \% \mathrm{NaCl}$ and SCA by ratios (4:1), (3:2) and (2:3) effect on plasticity index.

\section{EFFECT ON COMPACTION CHARACTERISTICS}

The effect of optimum percentages of $\mathrm{L}$ activated by $10 \% \mathrm{NaCl}$, sugar cane ash and combination of L activated by $10 \% \mathrm{NaCl}$ and SCA by ratios (4:1), (3:2) and (2:3) on max dry density and optimum moisture content are shown in Figures (12) and (13), respectively.

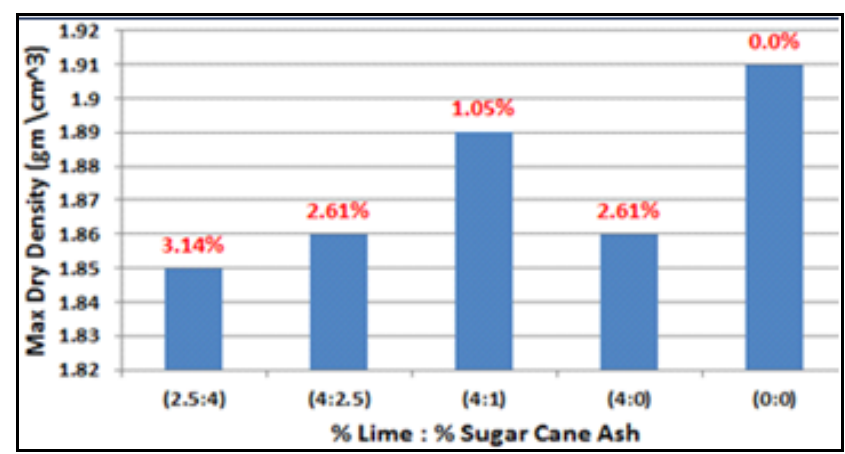

Fig. 13. The optimum percentages of $L$ activated by $10 \% \mathrm{NaCl}$, sugar cane ash, and combination of $\mathrm{L}$ activated by $10 \% \mathrm{NaCl}$ and SCA by ratios (4:1), (3:2) and (2:3) effect on max dry density.

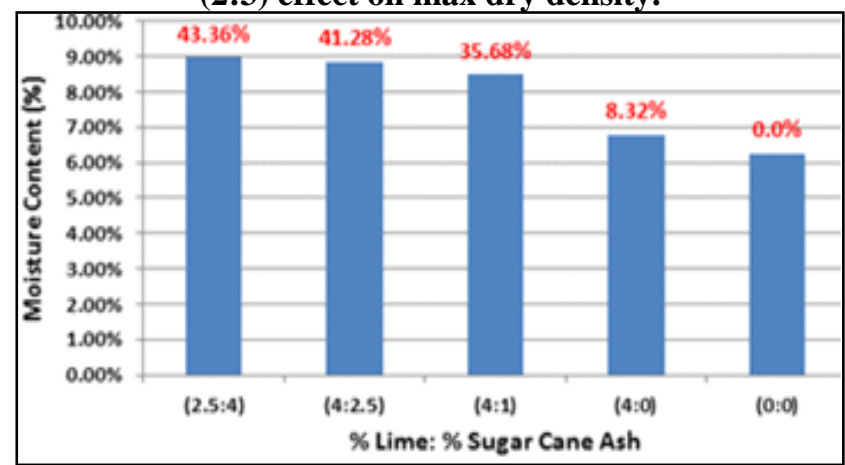

Fig. 14. The optimum percentages of $L$ activated by $10 \% \mathrm{NaCl}$, sugar cane ash, and combination of $\mathrm{L}$ activated by $10 \% \mathrm{NaCl}$ and SCA by ratios (4:1), (3:2) and (2:3) effect on moisture content.

\section{EFFECT ON CBR VALUES OF THE TESTED SOILS}

The optimum percentages of L activated by $10 \% \mathrm{NaCl}$, sugar cane ash and combination of $\mathrm{L}$ activated by $10 \% \mathrm{NaCl}$ and SCA by ratios (4:1), (3:2) and (2:3) effect on California bearing ratio (CBR) is shown in Figure (14).

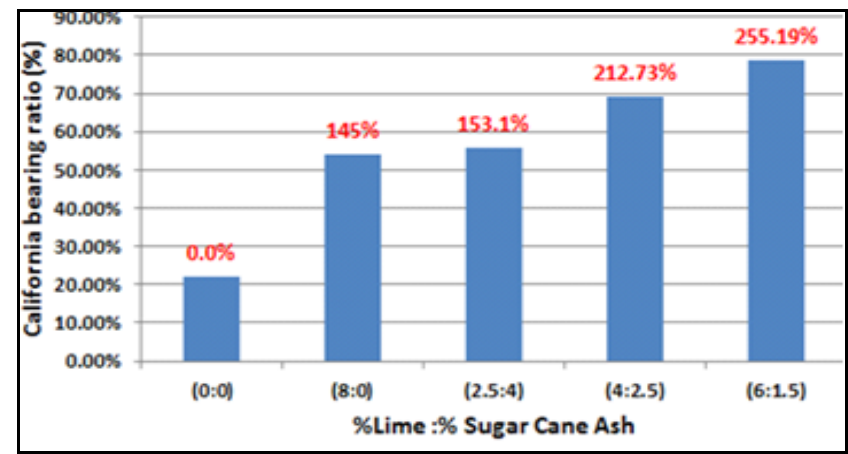

Fig. 15. The optimum percentages of $L$ activated by $10 \% \mathrm{NaCl}$, sugar cane ash, and combination of $\mathrm{L}$ activated by $10 \% \mathrm{NaCl}$ and SCA by ratios (4:1), (3:2) and (2:3) effect on california bearing ratio.

EFFECT ON \% SWELLING VALUES OF THE TESTED SOIL

The optimum percentages of $\mathrm{L}$ activated by $10 \% \mathrm{NaCl}$, sugar cane ash and combination of L activated by $10 \% \mathrm{NaCl}$ and SCA by ratios (4:1), (3:2) and (2:3) effect on percentage swelling are shown in Figure (15). 


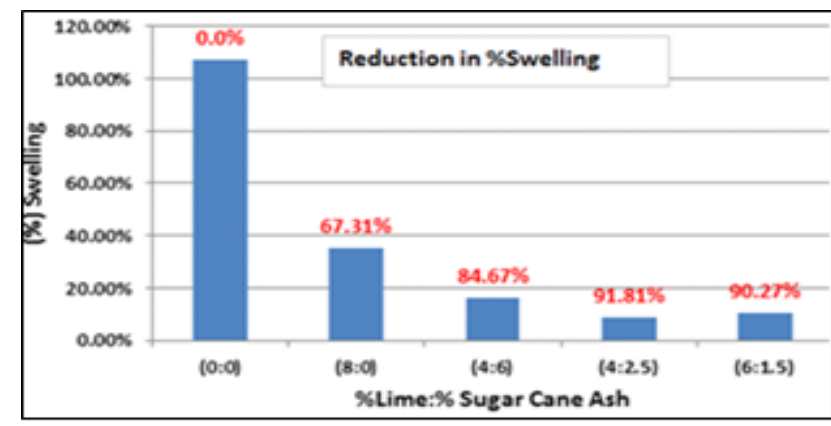

Fig. 16. The optimum percentages of $L$ activated by $10 \% \mathrm{NaCl}$, sugar cane ash, and combination of $\mathrm{L}$ activated by $10 \% \mathrm{NaCl}$ and SCA by ratios (4:1), (3:2) and (2:3) effect on percentage swelling.

\section{CONCLUSIONS}

(1) Adding both (L activated by NaCL) and combinations of ( $\mathrm{L}$ and SCA) to the test soil decrease Plasticity index (P.I).

(2) Adding $\mathrm{L}$ activated by $\mathrm{NaCl}$, SCA and combination between them to the test soil decreases max. dry density (MDD) and increases optimum water content (OMC).

(3) Adding $(8 \% \mathrm{~L}+10 \% \mathrm{NaCL})$ to the tested soil changes CBR\% from $22.14 \%$ to $54.23 \%$ with improvement of $145 \%$. While, adding (6\%L+1.5\%SCA) increases CBR\% to $78.64 \%$ with improvement of $255.19 \%$.

(4) Adding $(8 \% \mathrm{~L}+10 \% \mathrm{NaCl})$ to the tested soil changes swelling percentage (S\%) from $107.22 \%$ to $35.04 \%$ with improvement of $67.31 \%$. While, adding $(6 \% \mathrm{~L}+1.5 \% \mathrm{SCA})$ reduces $\mathrm{S} \%$ to $10.43 \%$ with improvement of $90.27 \%$.

(5) Sugar cane ash alone is not an efficient stabilizer, but still can be used to improve the engineering properties of clayey soil when mixed with lime.

(6) The pozzolanic reaction between the lime activated by sodium chloride, soil and sugar cane ash results in the formation of cementitious compounds.

(7) The classification of the tested soil changed from (CH- soil) to (MH- soil) after stabilization according to Unified Soil Classification System (USCS).

\section{REFERENCES}

1. Masued, G.G. (2017). "Effect Of Sugar Bagasse Ash On the Physical Properties Of Subgrade Layer". J. of Engng. Sustainable Development, Vol. 21, No. 5.

2. Mahapatra, S.R. and Sahoo, R.R. (2017). "Strength behavior Of Soil Stabilized With Fly Ash and Sugarcane Bagasse Ash". Dept. of Civil Engng., VSSUT, Burla, Odisha, India, Vol. 6(9), pp. 1-5.

3. Mir, B.A. and Sridhran, A. (2013). "Physical and compaction behaviour of clay soil-fly ash mixtures". Geotech. Geol. Eng., 31(4), pp 1059-1072.

4. Barasa, P.K.; Jonah, T.K. and Mulei, S.M. (2013). "Stabilization of Expansive Clay Using Lime and Sugarcane Bagasse Ash". Int. J. of Sc. and Res. (IJSR).

5. Muntohar, S. and Hantoro, G. (2000). "Influence of Rice Husk Ash and Lime on Engineering Properties of a Clayey Sub-grade". Electronic J. of Geotech. Engng., Vol. 5.

6. Abd El-Aziz M. et al (2004), "The effect of lime-silica fume stabilizer on engineering properties of clayey subgrade". Civil Engng. Dept., Cairo Univ. - Fayoum Branch.

7. Ouf, M.E. (2001). "Stabilization of subgrade soils using ground granulated blast furnace slag". $\mathrm{PhD}$, School of Civil Engineering, University of Leeds, U.K..

8. Negi, C.H. Yadav, R. K. and Singhai, A.K. (2013)". Effect of Silica Fume on Engineering Properties of Black Cotton Soil". Engng. Dept., JEC Jabalpur, (M.P.), India.
9. Mohamed, A. M. O.; Yong, R. N. and Mohamed, L. F. (1991). "Soil Improvement Using Chemical Treatment". Geotech. Engng. Conf., Cairo University, Egypt, pp. 53-63.

10. Milburn, P. and. Parsons, L. (2004). "Performance of Soil Stabilization Agents", Topeka, Kansas Univ. of Kansas Lawrence, Kansas, U.S.A.

11. Ahmed, I. A. (1988). "A Review of Soil Stabilization by Lime and Cement for Pavement Construction". M.Sc. Thesis, Civil Engng. Dept., Univ. of Leeds, U.K.

\section{AUTHORS PROFILE}

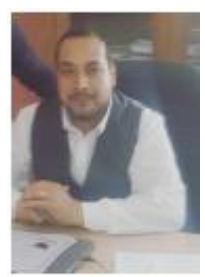

Name : Mahmoud Ali Mahmoud

Date of Birth : 27 November 1975

Nationality : Egyptian

Qualifications

1998 : B.Sc. Civil Engineering, Helwan Univ., Egypt.

2007 : M.Sc. Civil Engineering, Soil Mechanics, Helwan Univ., Egypt.

2013 : Ph.D. Civil Engineering, Soil Mechanics,

Helwan Univ., Egypt.

\section{Positions}

2003-2007 : Demonstrator/Assistant Lecturer.,Civil

Engineering Dept., Helwan Univ., Cairo, Egypt.

2013-Now : Lecturer. of Soil Mechanics and Foundations, Civil Engineering Dept., Helwan Univ., Cairo, Egypt.

Publications: Several academic papers in local and international journals.

Current Job: Teaching postgraduate courses in Soil Mechanics and Foundations. Supervision of B.Sc. Project on

Professional Activity: Geotechnical and Foundation Engineering.

- Consulting geotechnical engineer (6 years) - Design of foundations, temporary and permanent side support systems, groundwater control, remedy of underground structures.

- Consulting structural engineer (1 years).

- Member of the Board of the Egyptian Geotechnical Society.

- Execution of boreholes and field tests in all zones in Egypt.

- Carried out geotechnical survey and soil and foundation studies in all zones in Egypt.

- Design of all types of structures.

$\begin{aligned} & \text { Name } \\ & \text { Date of Birth } \\ & \text { Nationality }\end{aligned}$
$\begin{aligned} & \text { : Mohamed Rabah } \\ & \text { Egyptian } \\ & \text { Qualifications } \\ & 2003 \quad: \text { B.Sc. Civil Engineering, Helwan } \\ & \text { Univ., Egypt. }\end{aligned}$
$\begin{gathered}\text { U.Sc. Civil Engineering, Material, } \\ \text { Helwan }\end{gathered}$
$\begin{aligned} & 2016 \quad \text { Egypt. } \\ & \text { : Ph.D. Civil Engineering, Highway and }\end{aligned}$

\section{Positions}

2003-2016 : Demonstrator/Assistant Lecturer Civil Engineering Dept. Helwan Univ., Cairo, Egypt.

2016-Now : Lecturer. of Highway and Pavement design, Civil Engineering Dept., Russian Univ., Cairo, Egypt.

Current Job: Teaching undergraduate and postgraduate courses in Highway and pavement design..Supervision of B.Sc. Project on

Professional Activity:

$$
\text { Highway and pavement design. }
$$

- Member of the Egyptian Geotechnical Society.

- Member of the Egyptian engineering syndicate.

- Carried out Roads and highway survey and pavement studies in several zones in Egypt.

- Design of all types of structures.

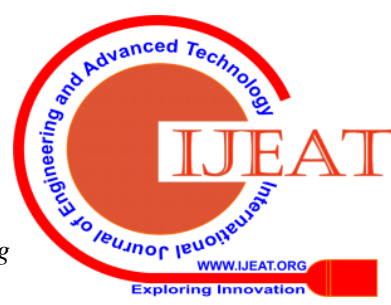




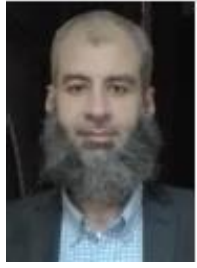

Name:Ahmed Abd elghany Mahmoud

Date of Birth : 24 September 1978

Nationality : Egyptian

Qualifications

2001 : B.Sc. Civil Engineering, Helwan Univ.,

Egypt.

2007 : M.Sc. Civil Engineering, Soil Mechanics,

Helwan Univ., Egypt.

2015 : Ph.D. Civil Engineering, Highways and

Traffic, Helwan Univ., Egypt.

Positions

2001-2015 : Demonstrator/ Assistant Lecturer., Civil Engineering Dept.,

Helwan Univ., Cairo, Egypt.

2015-Now : Lecturer. of Highways and Transportation.

, Civil Engineering Dept., Helwan Univ., Cairo, Egypt.

Publications: Several academic papers in local and international journals.

Current Job: Teaching undergraduated and postgraduate courses in Highways and Transportation. Supervision of B.Sc.

Professional Activity:

$$
\text { Project on Highways and Transportation. }
$$

- Member of the Egyptian Geotechnical Society.

- Member of the Egyptian engineering syndicate.

- Carried out Roads and highway survey and pavement studies in several zones in Egypt.

- Design of all types of structures.

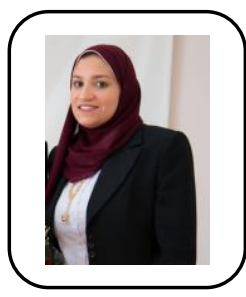

\section{Name : Nourhan Mahmoud Amin}

Date of Birth : 27 November 1975

Nationality : Egyptian

Qualifications

2016 : B.Sc. Civil Engineering, Helwan Univ.,

Egypt.

2019 : M.Sc. Civil Engineering, Soil

Mechanics, Helwan Univ., Egypt.

Positions

2016-2020 : Demonstrator/Lecturer Assistant., Civil

Engineering Dept., Russian Univ., Cairo, Egypt.

Current Job: Teaching undergraduate and postgraduate courses in Soil Mechanics and Foundations. Russian Univ.

Professional Activity:

- Member of the Egyptian Geotechnical Society.

- Member of the Egyptian engineering syndicate.

- Carried out Roads and highway survey and pavement studies in several zones in Egypt.

- Execution of boreholes and field tests in several zones in Egypt.

- Carried out geotechnical survey and soil and foundation studies in all zones in Egypt.

- Design of all types of structures.

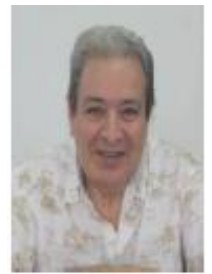

Name : Amr Mohamed Radwan

Nationality : Egyptian

Qualifications

1962 : B.Sc. Civil Engineering,

Cairo Univ., Egypt.

1966 : M.Sc. Civil Engineering, Soil

Mechanics, Assiut Univ., Egypt. 1974 : Ph.D. Civil Engineering, Soil

Positions

Mechanics, Strathclyde Univ., Glasgow, U.K.

1962-1982 : Demonstrator/Lecturer/Assistant Prof., Civil Engineering

Dept., Assiut Univ., Assiut, Egypt.

1985-Now : Assistant Prof./Prof. of Soil Mechanics and Foundations, Civil Engineering Dept., Helwan Univ., Cairo, Egypt.

1994-1997 : Dean, Faculty of Engineering at Mataria, Helwan Univ., Cairo, Egypt.

Publications: Several academic papers in local and international journals Two books - Two CDs on Soil Mechanics, Geotechnical and Foundation Engineering.

Current Job: Teaching postgraduate courses in Soil Mechanics and Foundations. Supervision of B.Sc. Project on Geotechnical and Foundation Engineering.

Professional Activity:

- Consulting geotechnical engineer (32 years) - Design of foundations, temporary and permanent side support systems, groundwater control, remedy of underground structures.

- Consulting structural engineer (14 years).

- Member of the Board of the Egyptian Geotechnical Society.

- Chairman of the Permanent Committee for the Egyptian Code for Soil

Mechanics,
- Design and Construction of Foundations, Ministerial Decree No. 245, 2010.

- Execution of boreholes and field tests in all zones in Egypt.

- Carried out geotechnical survey and soil and foundation studies in all zones in Egypt.

- Design of all types of structures. 